\title{
Diffusion Study of Cream Formula of Lyophilized Ethanol Extract of Moringa oleifera $\mathbf{L}$. Leaves
}

\section{(Studi Difusi Formula Krim Ekstrak Etanol Terliofilisasi Daun Kelor (Moringa oleifera L.))}

\author{
Amriani Sapra $^{1 *}$, Suwahyuni Mus ${ }^{2}$, Dwirandy $^{3}$, Rifka Malluka ${ }^{3}$, Nur Khairi ${ }^{1}$ \\ ${ }^{I}$ Department of Pharmaceutical Technology, Sekolah Tinggi Ilmu Farmasi, Makassar, Indonesia, 902422 \\ ${ }^{2}$ Department of Pharmacology, Sekolah Tinggi Ilmu Farmasi, Makassar, Indonesia, 90242 \\ ${ }^{3}$ Bachelor Students, Sekolah Tinggi Ilmu Farmasi, Makassar, Indonesia, 90242 \\ E-mail: amriani.sapra@gmail.com
}

Article Info:

Received: 4 September 2020

in revised form: 29 November 2020

Accepted: 10 September 2021

Available Online: 4 October 2021

Keywords:

Moringa leaf

Moringa oleifera $\mathrm{L}$.

Diffusion

The Skin of the snake

Penetration

Corresponding Author:

Amriani Sapra

Sarjana Farmasi

Sekolah Tinggi Ilmu Farmasi

Makassar

90242

Indonesia

email: amriani.sapra@gmail.com

\begin{abstract}
Background: Moringa oleifera L. leaves have analgesic activity due to their flavonoids content. These polar antioxidants compounds usually have difficulty to diffuse through the skin. Objectives: The purpose of this study was to evaluate the diffusion parameters of cream contains the lyophilized of M. oleifera leaves ethanol extract. Material and Methods: The lyophilized of M.oleifera leaves ethanol extract (5\%) formulated as an o/w cream with $2 \%$ of cetyl alcohol as a stiffening agent. The physical characteristics of the cream were determined for organoleptic, homogeneity, $\mathrm{pH}$, viscosity, spreadability, and type of emulsion parameters. The diffusion parameters were determined with Franz cell diffusion using the skin's snake as a membrane with $0 ; 10 ; 30 ; 60$ and 90 minutes sampling time. Results: Physical characteristics of the cream showed that $\mathrm{o} / \mathrm{w}$ as the cream type with $\mathrm{pH}$, viscosity, and spreadability value were $4.72 \pm 0.03 ; 14.000 \pm 225 \mathrm{cps}$; and $5.7 \pm 0.20 \mathrm{~cm}$, respectively. The diffusion parameter showed total flavonoids penetrate through the membrane was $360.134 \pm 0.20 \mu \mathrm{g} / \mathrm{cm}^{2}$ with flux $239,875 \mu \mathrm{g} / \mathrm{cm}^{2} \mathrm{hr}$. Conclusions: This study showed a cream formulation that fulfills the required physical characteristics standard and can deliver active compounds to penetrate through the membrane.
\end{abstract}

Copyright $(2019$ JFG-UNTAD This open access article is distributed under a Creative Commons Attribution (CC-BY-NC-SA) 4.0 International license.

How to cite (APA $6^{\text {th }}$ Style):

Sapra, A., Mus, S., Dwirandy, Malluka, R., Khairi N. (2021). Diffusion Study of Lyophilized Ethanol Extract of Moringa oleifera L. Leaf Cream. Jurnal Farmasi Galenika :Galenika Journal of Pharmacy (e-Journal), 7(2), 131-142. doi:10.22487/j24428744.2021.v7.i2.15275 


\section{ABSTRAK}

Latar Belakang: Daun kelor (Moringa oleifera L.) memiliki aktivitas analgetik karena mengandung senyawa flvanoid. Senyawa flavonoid pada umumnya merupakan senyawa polar yang susah untuk menembus kulit. Tujuan: Tujuan dari penelitian ini adalah untuk mengevaluasi parameter difusi sediaan krim ekstrak etanol daun kelor (Moringa oleifera L.). Metode: Liofilisat ekstrak etanol daun kelor (5\%) diformulasi menjadi krim tipe $\mathrm{m} / \mathrm{a}$ menggunakan setil alkohol 2\% sebagai stiffening agent. Evaluasi karakteristik fisik sediaan ditentukan melalui parameter organoleptik, homogenitas, $\mathrm{pH}$, viskositas, daya sebar dan uji tipe krim. Parameter difusi ditentukan dengan metode sel difusi franz menggunakan kulit ular sebagai membran dengan waktu sampling 0,10, 30, 60 dan 90 menit. Hasil: Hasil evaluasi fisik krim menunjukkan tipe krim m/a dengan pH 4,72 \pm 0.03 menghasilkan viskositas $14.000 \pm 225 \mathrm{cps}$ dengan daya sebar $5,7 \pm 0.20 \mathrm{~cm}$. Uji difusi menunjukkan jumlah kumulatif flavonoid yang terpenetrasi sebesar $360.134 \pm 0.20 \mu \mathrm{g} / \mathrm{cm}^{2}$ dengan flux $239,875 \mu \mathrm{g} / \mathrm{cm}^{2}$ perjam. Kesimpulan: Penelitian ini menunjukkan bahwa sediaan krim yang dibuat telah memenuhi persyaratan mutu fisik dan dapat menghantarkan senyawa aktif berpenetrasi melalui membran.

Kata kunci: Daun Kelor; Moringa oleifera L; Uji Difusi; Kulit Ular; penetrasi.

\section{INTRODUCTION}

Indonesia was a country rich in the natural compound foremost plant with higher potency as medicine and known as herbal medicine or phytotherapythat using plants or extracts as raw material (Pratiwi, et al., 2013). Plants are used as medicine because one or more chemical compounds have pharmacological activities. Moringa oleifera leaf is one of the plants that has been used as herbal medicine. Various studies about the use of Moringa leaf have been discovering, such as an analgesic, antipyretic, and anti-inflammatory. Another study showed that Moringa leaf has antioxidants, anticancer, and antimicrobial activities, later known it also decreases blood sugar levels (Ahisma, 2013; Sulastri E, et.al., 2018; Sulistyorini, et al., 2015; Yanti, 2010).

Moringa leaf contains chemical compounds include flavonoids, alkaloids, steroids, tannins, saponins, and terpenoids (Rohyani, et al., 2015). As a traditional medicine, empirically 2-3 bunch of Moringa leaf mashed with half of teaspoon of Piper betle were used as a liniment (Widyaningrum, 2011). A study of Muqsith (2015) showed that ethanol extract of Moringa leaf given orally at a dose of 400 $\mathrm{mg} / \mathrm{kg} \mathrm{BW}$ in mice has an analgesic effect. This study was supported by Sulistyawati (2016) found that ethanol extract of Moringa leaf at a dose of 25 and $50 \mathrm{mg} / \mathrm{kg} \mathrm{BW}$ has analgesic activity of $76.41 \%$ and $80.41 \%$. In Moringa leaf, alkaloids and flavonoids have responsibilities as an analgesic agents. Flavonoids can reduce pain by inhibiting the cyclooxygenase and lipoxygenase enzymnes (AlMuqsith, 2015) that lead to the distracting synthesis of prostaglandin and reduces pain (Suryanto, 2012). Furthermore, ethanol extract of Moringa leaf showed central and peripheral analgesic activity (Bhattacharya, A., et al., 2014).

A cream is a suitable dosage form for peripheral analgesia. It is easy to apply and spreadable. The cream can remain in the skin and allow the optimal release and diffusion of active ingredients (Sharon, et al., 2013). The ability of active ingredients to penetrate through the skin was a critical variable to 
measure the topical formulation effectivity. An in-vitro study of skin penetration related to bioavailability evaluation of active compounds by determining rate and quantities of active compounds penetrate through and remain in the skin (Benson, \& Watkinson, A. C., 2012). In spitefully, cream consistency affected by the cream base which is one of the remarkable variables in the formulation. This study was conducted to evaluate the diffusion profile of cream containing the lyophilized Moringa leaves ethanol extract with cetyl alcohols as a stiffening agent using the Franz cell diffusion method and the skin's snake as a membrane.

\section{MATERIAL AND METHODS}

\section{Materials}

M. oleifera leaf was obtained from Takalar Regency (South Sulawesi). The plant was identified at plant anatomy laboratory, Faculty of Science, Makassar National University (UNM). Aluminum chloride, alpha-tocopherol, stearic acids, phosphate buffer, DMDM Hydantoin, isopropyl myristate, ethanol 96\% (analytical grade), quercetin (Sigma-Aldrich), blue methylene, sodium acetate, liquid paraffin, phytocream ${ }^{\circledR}$ (a mixture of potassium palmitoyl hydrolyzed wheat protein (and) glyceryl stearate (and) Cetearyl alcohol), phenoxyethanol, propylene glycol, and cetyl alcohol.

\section{Methods}

Moringa leaf was dried at room temperature. The dried simplisia was milled to obtain a 2-3 mm particle and extracted with the maceration method for 72 hours with ethanol $70 \%$ as a solvent. The extract was separated from residues by filtration andrepeated three times. The filtrate was evaporated and then lyophilized with freeze dryer to remove the solvent (Depkes RI, 2008).

\section{Identification of flavonoid content}

About $10 \mathrm{mg}$ of weighed lyophilized extract were shaken with $3 \mathrm{~mL}$ of ethanol $70 \%$, then heated and shaken again and filtered it. This was followed by the addition of $0,1 \mathrm{~g}$ of Magnesium (Mg) powder and two drops of concentrated $\mathrm{HCl}$ into the filtrate. The red coloration in the ethanol layer showed the presence of flavonoids (Harbone, J.B., 1987).

\section{Cream formulation and preparation}

The oil phase was prepared by melting the stearic acids, liquid paraffin, cetyl alcohols, phenoxyethanols, and isopropyl myristate at $75^{\circ} \mathrm{C}$ mixing the ingredients uniformly. The aqueous phase was prepared by dissolving DMDM hydantoin and phytocream ${ }^{\circledR}$ in deionized water. The water 
phase was warmed to $75-80^{\circ} \mathrm{C}$ until all ingredients were dissolved, propylene glycol was later mixed. When the water and oil phase were at the same temperature, the oil phase was slowly added to the water phase with moderate agitation and kept stirred until the temperature dropped to $40^{\circ} \mathrm{C}$. Lyophilized extracts were dissolved in propylene glycol and alpha-tocopherol, and the solution were added to the cream base using homogenizer ultraturax. The mixture was homogenized for 15 minutes until the formulation became uniform. The exact concentration of each ingredients can be seen in Table 1.

Table 1. An o/w cream of lyophilized extract concentrations

\begin{tabular}{cc}
\hline Ingredient & $\begin{array}{c}\text { Concentration } \\
(\% \mathbf{w} / \mathbf{v})\end{array}$ \\
\hline Lyophilized extract & 5 \\
Cetyl alcohols & 2 \\
Stearic acids & 5 \\
Liquid paraffin & 6 \\
Propylene glycol & 15 \\
Isopropyl Myristate & 5 \\
Phytocream $^{\circledR}$ & 5 \\
DMDM Hydantoin & 0,2 \\
Phenoxyetanol $^{\text {Alpha-tocopherol }}$ & 0,5 \\
Aquadest & 0,05 \\
\end{tabular}

\section{Cream evaluation}

\section{Organoleptic characteristics}

All formulations were tested for physical appearance, color, texture, and homogeneity. These characteristics were evaluated by visual observation. Homogeneity was tested by applied cream to a glass object outline a thin film then covered with another glass. Textures were tested by pressing a small quantity of the formulated cream between the thumb and index finger. The consistency of the formulation and presence of coarse particles were used to evaluate the texture and homogeneity of the formulations (Mei. X, et al., 2016).

pH value

The $\mathrm{pH}$ value of each formulation was determined using a $\mathrm{pH}$ meter (LAQUA $\mathrm{pH}$ 1100). Measurements were made in triplicate. The $\mathrm{pH}$ meter was calibrated with standard buffer solutions ( $\mathrm{pH} 4,7$, and 10) before each use. The requirement $\mathrm{pH}$ value ranges from 4.5-6.5 (Tranggono, et al., 2007). 


\section{Viscosity measurement}

A Brookfield viscometer LV was used with a concentric cylinder spindle \#64 to determine the viscosity of the different topical formulations. The spindle was rotated at $6 \mathrm{rpm}$ values. The tests were carried out at $21^{\circ} \mathrm{C}$ and all measurements were made in triplicate.

\section{Spreadability test}

Applied $0.5 \mathrm{mg}$ of the cream between thin layer glass above a scale paper, place weighed mass $50 \mathrm{~g}$; $100 \mathrm{~g} ; 150 \mathrm{~g}$; and $200 \mathrm{~g}$ continuously. Spreadability test for all formulation were made in triplicate (Mei. X, et al., 2016).

\section{Type of cream evaluation}

The type of cream was evaluated by dilution and dye dispersion methods. About $0.5 \mathrm{~g}$ of the cream was placed into two vials followed by adding $10 \mathrm{~mL}$ of aquadest in one vial while another vial with two drops of blue methylene. The diluted and complete mixture with blue methylene of the cream showed an o/w cream. All evaluation were made in triplicate.

\section{Standard curve}

A standard quercetin solution of $10.000 \mathrm{ppm}$ was prepared by accurately weighed about $10 \mathrm{mg}$ quercetin in a flask and dispersed with ethanol $95 \%$ as a stock solution. Stock solution was then

diluted into 2 ppm, 4 ppm, 6 ppm, 8 ppm, and 10 ppm. Subsequently, $0.5 \mathrm{~mL}$ of solution from each concentration was mixed with $1.5 \mathrm{~mL}$ of ethanol $95 \%, 0.1 \mathrm{~mL}$ of potassium acetate $1 \mathrm{M}$ solution, 0.1 $\mathrm{mL}$ of aluminium chloride $10 \%$, and another $2.8 \mathrm{~mL}$ of aquadest. Each solution was then homogenized using a vortex for 1 minute and incubated at room temperature for 30 minutes. The absorbance for each concentration wasobtained by using the spectrophotometer UV-Vis at $427 \mathrm{~nm}$ and plotted to create a calibration curve (Bhandari, 2014).

\section{Total flavonoid content of lyophilized ethanol extract of Moringa leaf}

About $100 \mathrm{mg}$ of lyophilized ethanol extract of Moringa leaf was accurately weighed in a flask dispersed with ethanol $95 \%$ as the stock solution of $10.000 \mathrm{ppm}$. The total flavonoid content $(\mathrm{mg} / \mathrm{mL})$ was determined using aluminum chloride (AlCl3) method. The assay mixture consisting of $0.5 \mathrm{~mL}$ of the plant extract, $1.5 \mathrm{~mL}$ of ethanol $95 \%$, and $2.8 \mathrm{~mL}$ of distilled water was incubated for $30 \mathrm{~min}$ at $25^{\circ} \mathrm{C}$. This was followed by the addition of $0.5 \mathrm{~mL}$ of $10 \% \mathrm{AlCl} 3$ immediately and $0.5 \mathrm{~mL}$ of $1 \mathrm{M}$ 
potasium acetate to the reaction mixture. The absorbance was measured at $427 \mathrm{~nm}$. Quercetin was used as a standard (Subraanian, et al., 1969).

\section{Membrane preparation}

The skin's snake purchased from Bandung Zoo sized depend on Franz cell diffusion diameter and soaked with $\mathrm{NaCl} 0.9 \%$.

\section{Diffusion study of active compounds}

The Franz cell diffusion method used to evaluate the diffusion profile of the formulation (Nurwaini, S., \& Purbowati, A., 2019). Franz cell acceptor compartment filled with $50 \mathrm{~mL}$ of phosphate buffer solution (7.4). For the donor compartment, an amount of $2 \mathrm{~g}$ of cream preparation was initially set in a membrane (diameter $1.33 \mathrm{~cm} 2$ ). The temperature and stirrer speed carried out at $37 \pm 1^{\circ} \mathrm{C}$ and 120 RPM, respectively for 90 minutes. The experiments were conducted in triplicate and samples were evaluated at different time points. Absorbance was measured with a UV-Vis spectrophotometer at 427 $\mathrm{nm}$ as a maximum wavelength.

Total flavonoids penetrate through the diffusion area $\left(\mu \mathrm{g} / \mathrm{cm}^{2}\right)$ calculated with equation below

$$
\mathrm{Q}=\frac{C n \cdot V+\sum_{i=1}^{n-1} C . S}{A}
$$

With $\mathrm{Q}=$ total active compounds penetrate through the membrane $(\mu \mathrm{g} / \mathrm{cm} 2)$

$\mathrm{Cn}=$ active compounds concentration at the $\mathrm{n}$ minutes $(\mu \mathrm{g} / \mathrm{mL})$

$\mathrm{V}=$ acceptor compartment volume $(\mathrm{mL})$

$\sum_{i=1}^{n-1} C \quad=$ active compounds concentration penetrate minutes before $\left(\mu \mathrm{g} / \mathrm{cm}^{2}\right)$

$\mathrm{S}=$ sampling volume $(\mathrm{mL})$

A $=$ membrane area $\left(\mathrm{cm}^{2}\right)$

Penetration rate per hour (flux) calculated with Fick's I law :

$$
\mathrm{J}=\frac{M}{A \cdot t}
$$

$$
\begin{aligned}
\text { with } \quad \text { J } & =\operatorname{Flux}\left(\mu \mathrm{g} / \mathrm{cm}^{2} \text { perhour }\right) \\
\text { M } & =\text { mass of penetrating active compound }(\mu \mathrm{g}) \\
\text { A } & =\text { diffusion Unit area }\left(\mathrm{cm}^{2}\right) \\
\mathrm{t} & =\text { time (hour) }
\end{aligned}
$$




\section{RESULTS AND DISCUSSION}

In the current study, an assessment was carried out on the ethanol extract of Moringa leaves which was developed in the form of analgesic cream. Moringa leaves with analgesic activity was supported by the presence of chemical substances such as flavonoids and henolic compouinds. The results of phytochemical screening showed that Moringa leaf extract positively contained flavonoid compounds. The total flavonoid content of the lyophilized ethanol extract of Moringa leaves was $12.16 \%$. The results of determining the levels of flavonoids from the extract showed good results, allowing the ethanol extract of Moringa leaves to be developed as an analgesic. Several supporting studies have shown that the ethanol extract of Moringa leaves provides a strong analgesic effect (Sulastri et al.,2018; Battacharya et al.,2014). The flavonoid compounds in ethanol extract of M. oleifera are believed to reduce pain by inhibiting cyclooxygenase and lipoxygenase enzymes activity, that leads to the interrupting of prostaglandin synthesis (Suryanto, 2012)

The lyophilized extract was then made into a $5 \%$ oil-in-water type cream preparation using $2 \%$ cetyl alcohol as a base and phytocream ${ }^{\circledR}$ (a mixture of potassium palmitoyl hydrolyzed wheat protein (and) glyceryl stearate (and) Cetearyl alcohol) as an emulsifying agent. Cetyl alcohol as a stiffening agent influences viscosity and the ability of active compound to be releaseed from the dosage form. A hydrophilic active compound in the preparation expects to be easily released from the lipophilic cream base like cetyl alcohols to enhance the diffusion rate. In this study, phytocream ${ }^{\circledR}$ was used as an emulsifying agent because it is a combination of vegetable lipoproteins and lipids that have function as surfactants, the emulsification of wheat protein was very stable and suitable for the usage of cream (Ermina P., \& Marzuki A., 2017). According to Zulham et al. (2019), the cream prepared with phytocream ${ }^{\circledR}$ as an emulgator showed good physical stability after accelerated condition rather than the cream prepared with viscolam ${ }^{\circledR}$ and Novomer ${ }^{\circledR}$. The organoleptic properties (including physical appearance, color, odor, texture, and homogeneity), $\mathrm{pH}$, viscosity, and spreadability of the cream formulations can be seen in Table 2. The obtained cream has a light green color with a specific extract odor, smooth texture with no greasiness or coarse particle, and homogenous semi-liquid form. The $\mathrm{pH}$ value of the cream was $4.72 \pm 0.03$ and met the requirement for topical preparation (4.5-6.5). Topical preparation with low $\mathrm{pH}$ value causes skin irritation, while a high $\mathrm{pH}$ value causes dry skin (Sharon, et al., 2013).

The viscosity value of the cream was $14.000 \pm 225 \mathrm{cps}$ and spreadability $5.8 \pm 0.2 \mathrm{~cm}$. The viscosity relates to the distribution of the cream when applied besides the diffusion process of active compound released from the dosage form. Spreadability is an important characteristic of formulations, that responsible for the correct dosage transfer to the target site, extrudability from the package, and easy application on the substrate. 
Table 2. The physical characteristicsof lyophilized extract cream

\begin{tabular}{ccccc} 
Dosage & \multicolumn{4}{c}{ Physical Characteristics } \\
\cline { 2 - 5 } form & Organoleptic & pH & Viscosity & Spreadability \\
\hline $\begin{array}{c}\text { An o/w } \\
\text { cream }\end{array}$ & $\begin{array}{c}\text { Color : Light green } \\
\text { Odor : specific } \\
\text { extract }\end{array}$ & & & \\
& Texture : soft & $4.72 \pm 0.03$ & $14.000 \pm 225 \mathrm{cps}$ & $5.8 \pm 0.2 \mathrm{~cm}$ \\
& $\begin{array}{l}\text { Homogeneity : } \\
\text { Homogeneous }\end{array}$ & & & \\
&
\end{tabular}

Diffusion study of Moringa leaf extract cream carried out by Franz cell diffusion method with sampling time interval $0 ; 10 ; 30 ; 60$ and 90 minutes. The active compound penetration illustrates by using the snake's skin as a membrane between the donor compartment and the acceptor compartment. The snake's skin has a similar histopathological profile with the human stratum corneum but without pores (Sriarumtias, F.F. et al., 2017). The membrane is placed directly in contact with the suitable skin $\mathrm{pH}$ buffer (7.4) in the acceptor compartment. The stirring process in the acceptor compartment medium is useful to prevent saturation of the diffusion layer around the membrane (Sapra, A. \& Riski., R., 2019). The formation of bubbles or a whirl flow causes space to restrain active compounds toward the receptor compartment (Lanimarta, Y., 2012).

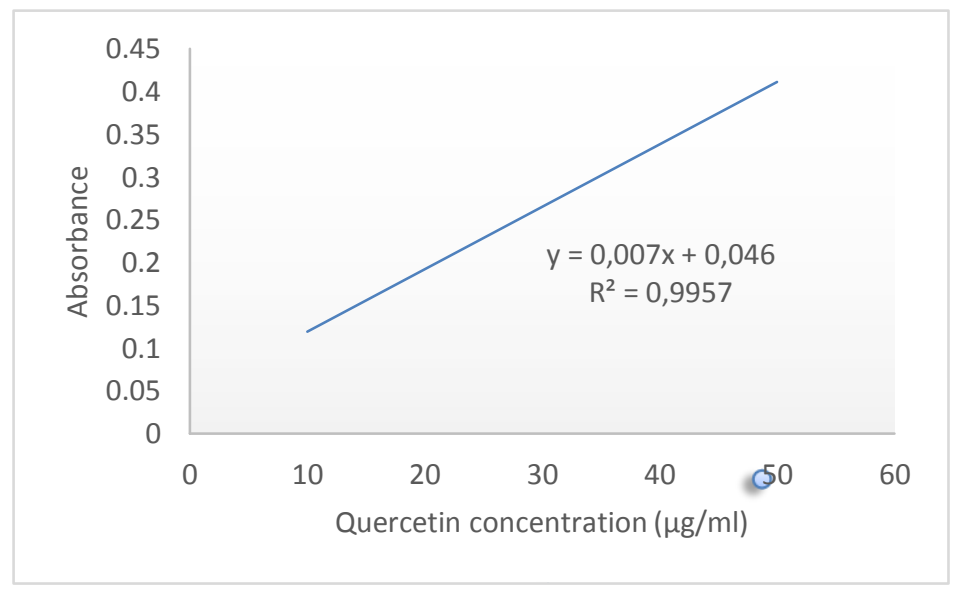

Figure 1. Calibration curve of the quercetin standar solution

The diffusion study aimed to see the diffusion profile of dosage form based on the cumulative amount of flavonoids permeated through the membrane per unit area and per unit time. The absorbance of the compounds penetrated through the snake's skin membrane to the acceptor fluid is determined using a $\mathrm{UV}-\mathrm{Vis}$ spectrophotometer at a wavelength of 427 as $\lambda \max$ of quercetin. The concentration of flavonoids in the acceptor fluid calculate based on the calibration equation $y=0.007 x+0.046$ with a correlation coefficient value of 0.995 (Figure 1) while flavonoid content of the extract was about $12.16 \%$. 


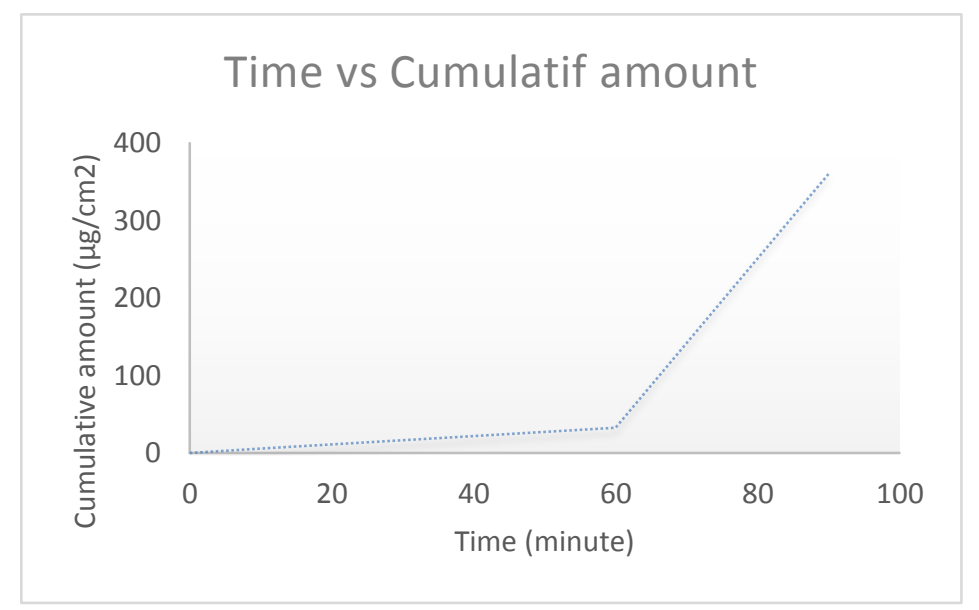

Figure 2. Cumulative amount of flavonoid permeated from the formulation for 90 minutes $\left(\mu \mathrm{g} / \mathrm{cm}^{2}\right)$

Figure 2 showed the data analysis of the cumulative number of flavonoids $\left(\mu \mathrm{g} / \mathrm{cm}^{2}\right)$ vs time. There was a significant increase in the cumulative number of flavonoids from 60 minutes to 90 minutes with a cumulative number of about $360.134 \pm 0.20 \mu \mathrm{g} / \mathrm{cm}^{2}$ at 90 minutes. At the initial time, the cumulative number of flavonoids was relatively low and constant, this maybe because the extract contains polar flavonoids that make it difficult to penetrate through the snake's skin membrane (Momuat, LI. et al., 2015). The number of active substances that passed through the membrane per unit time (flux) is about $239.875 \mu \mathrm{g} / \mathrm{cm}^{2}$ per hour. Other in vitro release profiles of flavonoids study reported by Vaisakh and Pandey (2012) from different cream formulation, showed the similar amount of flavonoids permeated. They reported that after 4 hours amount of flavonoids permeated range between 187-463 $\mu$ g (Vaisakh and Pandey., 2012).

\section{CONCLUSION}

The lyophilized ethanol extract of Moringa oleifera L, formulated into an oil-in-water cream (5\%) using $2 \%$ of cetyl alcohol as a stiffening agent and $5 \%$ of phytocream ${ }^{\circledR}$ as an emulsifying agent performs cream with physical characteristics that meet the quality requirements. Flavonoids as an active compound can penetrate through the snake skin membrane beyond the possibility as an analgesic candidate therapy.

\section{ACKNOWLEDGEMENT}

Authors acknowledge the Ministry of Education and Culture for funding thus research through 2020 PDP grant research. 


\section{CONFLICT OF INTEREST}

Authors declare that there is no conflict of interest.

\section{REFERENCES}

Ahisma, G. K. (2013). Aktivitas Antikanker Air Daun Kelor (Moringa oleifera 1.) terhadap Cell Line Kanker Serviks Hela dengan Uji Sitotoksisitas, Apoptosis, dan Jalur Induksi Apoptosis berdasarkan Ekspresi Gen p53. Universitas Gajah Mada.

Almeida, J.F., Reis, A.S.et.al. (2017). Lyophilized bee pollen extract: A Natural Antioxidant Source to Prevent Lipid Oxidation in The Refrigerated Sausage. Food Science and Technology, $7^{\wedge}($ Part B), 299-305.

Al-Muqsith. (2015). Uji Daya Analgetik Infusa Daun Kelor (Moringa oleifera) pada Mencit (us musculus) Betina. Universitas Malikussaleh.

Baud G.S., Sangi M.S., \& Koleangan H.S.J. (2014). Analisis Senyawa Metabolit Sekunder dan Uji Toksisitas Ekstrak Etanol Batang Tanaman Patah Tulang (Euphorbia tirucalliL.) dengan Metode Brine Shrimp Lethality Test (BSLT). Journal Ilmiah Sains, 14(2), 106-112.

Benson, H. A. E., \& Watkinson, A. C.,. (2012). Topical and Transdermal Drug Delivery: Principles and Practice. A John Wiley \& Sons Inc. Publication.

Bhandari and M. Rajbhandari. 2014. Isolation of Quercetin from Flower Petals, Estimation of Total Phenolic, Total Flavonoid and Antioxidant Activity of The Different Parts of Rhododendron arboreum Smith. Scientific World. 12 (12):

Bhattacharya, A., Kumar, S., Mishra, S., Patnaik, S., Sahu, P., \& Agrawal, D.,. (2014). Analgesic Effect of Ethanolic Leaf Extract of Moringa oleifera on Albino mice. Indian Journal of Pain, $28,89$.

C.C. Chang, M.H. Yang, H.M. Wen, and J.C. Chern, (2002), Estimation of Total Flavonoid Content in Propolis by Two Complementary Colorimetric Methods. Journal of Food and Drug Analysis. 10 (3), 178-182 (2002).

A., Kumar, S., Mishra, S., Patnaik, S., Sahu, P., \& Agrawal, D.,. (2014). Analgesic Effect of Ethanolic Leaf Extract of Moringa oleifera on Albino mice. Indian Journal of Pain, 28, 89. 
Departemen Kesehatan Republik Indonesia., 2008, Farmakope Herbal Indonesia Edisi I, Departemen Kesehatan Republik Indonesia: Jakarta

Ermina P., \& Marzuki A. (2017). Stabilitas Fisik SediaanKrim Ekstrak Etanol Kulit Batang Banyuru (Pterospermum celebiqum Miq.) dengan Variasi Phytocream®. Proceeding of Mulawarman Pharmmaceutical Conferences, 5(1), 48-58.

Harbone, J.B. (1987). MetodeFitokimiaPenuntun Cara Modern Menganalisis Tumbuhan. Institut Teknologi Bandung.

Lanimarta, Y.,. (2012). Pembuatan Dan Uji Penetrasi Nanopartikel Kurkumin - Dendrimer Poliamidoamin ( Pamam ) Generasi 4 Dalam Sediaan Gel Dengan Menggunakan Sel Difusi Franz. Universitas Indonesia.

Mei, X. Chen., Kenneth, S. Alexander, and Gabriella Baki, (2016), Formulation and Evaluation of Antibacterial Creams and Gels Containing Metal Ions for Topical Aplication, SJournal of Pharmaceutics, Article ID 5754349.

Momuat, LI., Suryanto E, Rantung O, Korua A, \& Datu H,. (2015). Perbandingan Senyawa Fenolik dan Aktivitas Antioksidan Antara Sagu Baru, Segar dan Kering. Chem Progress, 8(1), 20-29.

Nurwaini, S., \& Purbowati, A.,. (2019). Kombinasi Asam Oleat Dan Propilen Glikol sebagai Enhancer Cold Cream Verapamil untuk Penghantaran Transdermal. The 10th University Research Colloqium 2019, 998-1010.

Pratiwi, R., Posangi, J., \& Fatimah, W.,. (2013). Uji Efek Analgesik Ekstrak Etanol Daun Gedi (Abelmoschus manihot (1.) medik) pada Mencit (Mus musculus). Jurnal E-Biomedik (EBM), 1(1), 571-580.

Rohyani, S. I., Ariyanti.E., \& Suripto.,. (2015). Kandungan Fitokimia Beberapa Jenis Tumbuhan Lokal yang Sering Dimanfaatkan sebagai Bahan Baku Obat di Pulau Lombok. Universitas Mataram.

Sapra, A., \& Riski., R.,. (2019). Uji Difusi dan Iritasi Krim Solid Lipid Microparticle Ekstrak Etanol Daun Kersen (Muntingia calabura L.). Journal of Pharmaceutical and Medicinal Science, 4(1), 6-9.

Sharon, N., Anam, S., \& Yuliet. (2013). Formulasi Krim Ekstrak Etanol Bawang Hutan (Eleutherine palmifolia L. Merr). Online Journal of Natural Science, 2(3). 
Sriarumtias, F.F., Tarini, S., \& Damayanti, S.,. (2017). Formulasi dan Uji Potensi Antioksidan Nanostructures Lipid Carrier (NLC) Retinil Palmitat. Acta Pharmaceutica Indonesia, 42(1), $25-31$.

Subramanian SS, Nagarajan S. (1969). Flavonoids of the seeds of Crotlaria retusa and C. striata. Curr Sci. ;38:65-8.

Sulastri E, et.al. (2018). Thotal Phenolic, Total Flavonoid, Quercetin Content and Antioxidant Activity of Standarized Extract of Moringa oleifera Leaf from Region with Different Elevation. Pharmacognosy Journal. 10:s104-s108.

Sulistyorini, R., Sarjadi, Johan, A., \& Djamiatun, K.,. (2015). Pengaruh Ekstrak Etanol Daun Kelor (Moringa oleifera) pada Ekspresi Insulin dan Insulitis Tikus Diabetes elitus. Majalah Kedokteran Bandung, 47(2), 69-76.

Suryanto, E. (2012). Fitokimia Antioksidan. PMN.

Tranggono, Retno I., \& Latifah. F.,. (2007). Buku Pegangan Ilmu Pengetahuan Kosmetik. PT Gramedia Pustaka Utama.

Vaisakh, M.N, \& Pandey,. (2012). Assesent of Flavonoid Release With Different Permeation Enhancers. International Journal of Pharmaceutical Science and Drug Research. 4(2): 154156.

Widyaningrum, H. (2011). Kitab Tanaman Obat Nusantara. Med Press.

Yanti, M. L. (2010). Uji Efek Antipiretik Infusa Daun Kelor (Moringa oleifera lamk) pada Kelinci Putih Jantan Galur New Zealand. Universitas Muhammadiyah Surakarta.

Zulham, Sapra A., Rahayu S., (2019). Prosiding Seminar Nasional Kefarmasian Disrupsi Pelayanan Kefarmasian : Peluang atau Tantangan. Formulasi dan Evaluasi Krim Ekstrak Etanol Daun Pare (Momordica charantia L.) dengan Variasi Eulgator (pp.54-58). Makassar. Sekolah Tinggi Ilmu Farmasi Makassar. , 